\title{
The impact of organizational commitment, job satisfaction, job stress and leadership support on turnover intention in educational institutes
}

\author{
Saba Iqbal \\ Department of Management Sciences, The Islamia University of Bahawalpur, Pakistan \\ Email:sabe_2827@yahoo.com \\ Sadia Ehsan \\ Department of Management Sciences, The Islamia University of Bahawalpur, Pakistan \\ Email: sadia_ehsan90@yahoo.com
}

Muhammad Rizwan

Lecturer, Department of Management Sciences

The Islamia University of Bahawalpur, Pakistan

E-mail: rizwan.arshad@iub.edu.pk

Mehwish Noreen

Department of Management Sciences, The Islamia University of Bahawalpur, Pakistan

Email: mehwish828@gmail.com

Doi:10.5296/ ijhrs.v4i2.5906

URL: http://dx.doi.org/10.5296/ ijhrs.v4i2.5906

\begin{abstract}
For the attainment of individual's cognitive and social benefits the employee turnover is becoming popular trend in all organization. This research paper reports on examination of variables that may be predictive to leave a job. More precisely this current paper shows the direct and indirect impact of job stress, job satisfaction on turnover. Organizational commitment is the antecedent of turnover intention. It highlights the impact of leadership support on job satisfaction. In order to collect the data for understanding the situation about the employee turnover intention, a sample of 200 respondents was ask to participate in a self-administered questionnaire.50 questionnaires are not giving right answers so only 150
\end{abstract}


samples are selected for research. The current research paper uses a non-probability technique of sampling. We choose this sample of people from different institutions of Bahawalpur. Four major clusters was target to collect the sample data like the Islamia University of Bahawalpur, Allama Iqbal college of Bahawalpur, Army public school and college system and Sadiq Public School. Finding shows that employee turnover intention has a significant relationship with all the variables i.e. organizational commitment, job satisfaction, job stress and leadership support.

Keywords: Employee turnover intention, organizational commitment, leadership support, job satisfaction and job stress

\section{Introduction}

One of the most essential topics in almost all organization is turnover intention of employees. Organizations world wild face many challenges with the growing integration of the world economy into a single, huge market place resulting in strong universal competition. Beside keeping pace with the hi-tech advances, it is too difficult for an organization to be able to keep its best staff in the face of globalization and work force variety.

Together an organization's employee can provide a foundation of competitive advantages that is difficult for the competitor to copy. Turnover intention is one of the most important predictors in the actual turnover and commitment to the organization is one of the most vital ancedent to turnover intention. Intention to quit is serious issues mainly in the field of HRM (Human Resource Management). This is focus on market clearing stage on the costs linked with high labor turnover. Intention to leave a job is define as an 'individual's own expected chance (subjective) that they are quitting the organization permanently at some spot in the near future (Vandenberg and Nelson 1999, p. 1315). Thus intention is exact indicators of succeeding behaviour, yet the reasons for these intentions are frequently unfamiliar (Firth et al., 2004). Turnover cost consists of cost of recruiting and selecting new staff when already working employees leaves a job. Turnover cost also consist of the cost of loss of sales which occur because new staff members has low experience as compared to previous worker. If an employee wants to leave a job and his contribution is high in company, then company has to pay more wages to that employee because the losses of a company bear is much larger than paying a high wage to the employee.

"How organizations decide employee turnover?" The response to this query has big consequence to the person who may be thinking about leaving a job, and for the executive who meet with need of worker permanence, the elevated expenses drawn in the initiation and guidance of fresh personnel, and, not slightest, problems of organizational yield. While actual quitting behavior is the most important focus of attention to employers and researchers, objective to leave is supposed to be a tough substitute indicator for such actions. Lack of job satisfaction and Job stressors are main reasons that's contributed to people's to leave their jobs (Moore, 2002).

Desirable turnover, undesirable turnover and unavoidable turnover are categories of turnover 
intention. Family issue or departure and illness are main reasons of unavoidable turnover. Furthermore the turnover occurs due to lack of skill is known as desirable turnover. And last one, turnover occurs due to organizational issues such as poor support, lack of management, and role conflict is known as undesirable turnover. It includes capable and skilled employees who are quitting the organization. These organizational issues require to be addressed, as they are directly affect customer service quality and organization effectiveness. Organization may be quit by the employees either voluntary or involuntary. The voluntary turnover is a type of turnover in which an employee's choice to finish the relationship of employment. Whereas, the employer choice to finish the relationship of employment is involuntary turnover. Turnover intention separates organizational commitment from decision to quit. Actually, intention to leave a job is the direct antecedent of turnover behavior and shows a combination of withdrawal associated attitudes.

When an individual perceives that he or she does not provide desirable and unique resources or abilities to an organization, the adaptive response is to find another niche to occupy by searching for another job (Brown et al., 2007). From the individual viewpoint, when an employee is put in a latest situation with a new task, employee needs to learn how to fit with their organization norms, values, politics and culture. Person organization fit enables employee to get up quick to fit with the culture and surroundings. According to Porter (1974), it recognized that commitment of organization has a affirm belief and willingness of the employees to put maximum effort for the organization. A better commitment exists; the more workers are making a value role to the organization rather than to quit the organization. Moreover, when a worker shows an elevated level of commitment, it shows the employee is more probable to settle in the organization.

Turnover can be harmful or helpful to the organizations. One of the harmful cost of turnover is the personal cost linked with the hiring, recruitment, guidance and development of new workers to replace the workers who voluntary leave the organization. If the employee turnover rate is more then selection and recruitment become a main purpose of organization, thus raising its managerial concentration. If the poor employees are encourage to leave the organization, new employee that are creative can be hired at their position in the organization.

This current research paper reports on examining the variables that may be predictive to quit the job. More precisely this current paper shows the direct and indirect impact of job stress, job satisfaction on turnover. Organizational commitment is the antecedent of turnover intention. It highlights the impact of leadership support on job satisfaction.

Organizational commitment has generally been defined as identification and attachment with the organization. Job satisfaction is defined as an individual's, emotional, cognitive and evaluative response for his or her employment. Job stress is unfavorable reaction people have to excess pressures or other type of order place on them at job. Leadership support is defined as the degree of consideration and support a person get from his or her direct supervisor (Rizwan et al., 2013). 


\section{Literature Review}

\section{Turnover Intention}

Turnover intention as presently defined is an employee's preference to quit his or her job. Real turnover has been looked to be especially likely the result of intentions to withdraw (Harrison et al., 2006). Intention to leave a job is "a deliberate and conscious determination to quit the organization". Scholars term turnover intention as "person" own expected probability (subjective) that they are quitting the organization permanently at some spot in the close to future" (Liu \& Low, 2011). Turnover intention as currently understandable as an employee's preference to quit his or her organization refers that an employee's is unable to remain the organizational part (Lacity et al., 2008). Bodla \& Hameed (2008) suggested that the employees' turnover will have significant cost or risk of losing social assets. The research also found the measurement on the employees' turnover intention, which is an uncontrollable and controllable force. There are five variable that been identify, which is the satisfaction with management, satisfaction with salary, satisfaction with working conditions, Job stress and organizational commitment. According to Jeffrey (2007), if the mistrust of management is pervasive and disappointment among workers would lead to decreasing job tenure, increasing turnover intention. As a result, employer shouldn't lose sight of this factor. While the researchers who are conducting research want to perfectly know turnover behavior, while in authenticity, it is frequently complicated to empirically observe the behavior. While in reality, researchers generally survey recent workers and turnover intention is ask by them. Intentions to leave a job is consistent predictor of turnover behaviors. Considerable empirical proof supports the theory that attitude affects behavior more than behavior affects attitude (Lacity et al., 2008). On the bases of above definitions, turnover intention can be defined as the wish of workers to intentionally make a choice to leave the recent organization in the near future. Intention to leave is one of the antecedents of actual turnover. A number of antecedents have been identified by many scholars for turnover intention. These include irritation with jobs, violation of psychological contract and organizational commitment (Orvis et al., 2008). The determinants of employee turnover have great application to the employee who is thinking about quitting, also for the executive who is faced with the lack of employee stability, In the orientation and guidance of new employees and the issue of organizational output high costs involved ( Siong, Mellor, Moore \& Firth, 2006; Firth et al., 2004). According to Lehane and McCarthy Tyrrell (2007), intentions are the most direct determinants of exact behavior.

\section{Organizational Commitment}

Organizational commitment can be defined as identification and attachment with the organization (Mathieu and Zajac, 1990). The emotional reply to a optimistic assessment of the work environment is also known as organization commitment (Testa, 2001; Rizwan et al., 2013). These emotional answer may be considered an attachment, mainly when the person believes strongly in the organization's goals, values and demonstrates a strong need to maintain association in the organization (Scholarios and Marks, 2004). Extremely loyal staffs of the organization are less likely to leave the organization as compared to less committed 
employees of the organization (Joiner et al., 2004; Near, 1989). This study shows the variables of emigrant correction by combining the theoretical constructs of psychological barriers to adjustment, , socio-cultural adjustment, psychological contract and emotional adjustment in organization and their antecedents. Turnover intention is directly affected by the organizational commitment.. Organizational commitment is negatively related to turnover intentions according to many studies of past.

\section{H1: Organizational commitment has a negative influence on turnover intentions.}

\section{Job Satisfaction}

Job satisfaction is defined as an individual's cognitive, evaluative and affective reactions towards his or her job. Large amount of researches are present which link the job satisfaction with turnover intentions (Williams et al., 2001). In the study of occupational attitudes, Job satisfaction and organizational commitment are the most important topics (Kontoghiorghes and Bryant, 2004; Testa, 2001). From past findings it is clear that job satisfaction has a direct effect on turnover intentions as well as an indirect effect through organizational commitment (Blau, 1987). The relationship of job satisfaction with turnover intention and organizational commitment is more supported by many studies which recognize job satisfaction as an antecedent of organizational commitment (Lin and Ma, 2004b; Tett and Meyer, 1993). As a positive emotional reaction, it is rational to suppose that job satisfaction would be negatively related to behavioral turnover intention (Susskind et al., 2000). Consequences of frequent studies have given the proof of a strong negative relationship of job satisfaction with turnover intentions (Mannheim et al., 1997; Abraham, 1999). After an interference to enlarge the degree of employee satisfaction, turnover intentions decrease considerably (Abraham, 1999).

\section{H2: Job satisfaction has a negative influence on turnover intentions.}

\section{H3: Job satisfaction has a positive influence on organizational Commitment.}

\section{Job Stress}

Job stress is adverse reaction people have to excess pressures or other type of command place on them at work. The fundamental effect between job stress and job satisfaction has been hypothesized (Williams et al., 2001), empirically experienced (Lee and Ash forth, 1993), and subject to Meta-analysis (Sullivan and Bhagat,1992).

The regular results prove that job stress is cause of large number of attitudinal and behavioral and outcomes such as commitment to organization, job dissatisfaction, and a turnover intention (Barsky et al., 2004). Moreover, when employees feel stress on their jobs, it increase their job dissatisfaction. Wunder et al. (1982) found that job stressors had a direct 
negative effect on job satisfaction among managers of a large international company, and job stressor led to a decrease turnover intention commitment to organization, and actual quitting behavior. While, some studies have establish no direct relationship between stressors and turnover intention, but indirect effects due to continues experience of social support, satisfaction, job stress, and lack of organization commitment. Therefore, evaluation of the direct and indirect effects of job stressors on intention to leave a job has become an important concept.

\section{H4: Job stress is inversely related to job satisfaction.}

H5: Job stress has a direct positive relation with a turnover intention.

\section{Leadership Support}

It is defined as the extent of consideration and support a person perceives from his or her direct manager. This definition is reliable with the path-goal theory view that a helpful manager provides supervision to his or her social group, considers their input to be variable treats them fairly (House and Dessler, 1974). Amny researches shows that job satisfaction is an outcome of leadership support. As earlier stated, while the literature reports a constant relationship between leadership helpful behaviors and job satisfaction, Brown and Peterson (1993) stated a strong correlation between job satisfaction and leadership consideration whereas the correlation between leadership behavior and turnover intentions is less pronounced (Brown and Peterson, 1993). As such, we hypothesize that the effect leadership helpful behaviors have on turnover intentions is not direct through its effect on job satisfaction.

\section{H6: Leadership support positively influences job satisfaction.}

\section{Research Methodology}

The current research is descriptive in its nature. Descriptive research can be explained as some phenomenon, describing something, or any particular situation. Descriptive researches are those researches that explain the existing situation instead of interpreting and making judgment (creswell 1994). The main aim of the descriptive research is confirmation of the develop hypothesis that reflect the current situation. Descriptive research provides information about the current situation.

\subsection{Sample/ Data}

In order to collect the data for understanding the situation about the employee turnover intention, a sample of 200 respondents will ask to participate in a self-administered questionnaire.50 questionnaire are not giving right answers so only 150 samples are selected 
for research. The current study utilizes a non-probability sampling technique that is convenience sampling. Convenience sampling is a sampling technique that obtains and collects the relevant information from the sample or the unit of study that are conveniently available (Zikmund, 1997).convenience sampling is normaly used for collecting a large number of completed surveys speedily and with economy (Lym et al.2010).

We select these sample members from different institutions of Bahawalpur. Four main clusters will target to collect the sample data like the Islamia University of Bahawalpur, Allama Iqbal College Bwp, Army public school and college system, Sadiq public school.

\subsection{Instrument and Measure}

The survey instruments of the current study address two major purposes: first is to analyze the relationship of different variables of employee turnover intention. Second, to collect information about different characteristics of the respondents that can be used to understand the variations in different categories.

The survey instrument contains two sections. It includes different personal demographic variables. This section will obtain the respondent's information about gender, age, income, education, status and the company.

The latent variables that are important in the current study includes employee turnover intention, organizational commitment, job satisfaction, job stress and leadership support. This section of the study is developed based on the past literature and questionnaire.

The scales of the study were adopted from the previous literature and published studies. The first variable was employee turnover intention has three items and these scales were taken from Cummann et al. (1979). The next variable was organizational commitment having eight items and these scales were taken from Porter et al. (1974). The other variable was job satisfaction having five items and these scales were taken from. Next variable was job stress having four items and these scales were taken from Cohen et al.(1983). Last variable was leadership support having five items and these scales were taken from House and Dessler (1974).

Table1: Scales of the Study

\begin{tabular}{|l|l|l|l|}
\hline Sr \# & Variable & Items & Reference \\
\hline $\mathbf{1}$ & $\begin{array}{l}\text { Employee } \\
\text { turnover intention }\end{array}$ & $\begin{array}{l}\text { 1- I will likely actively look for a new job in } \\
\text { the next year. } \\
\text { 2- I often think about quitting. } \\
\text { 3- I probably look for a new job in the next }\end{array}$ & $\begin{array}{l}\text { Cummann } \\
\text { et al. (1979) }\end{array}$ \\
\hline
\end{tabular}




\begin{tabular}{|c|c|c|c|}
\hline & & year. & \\
\hline 2 & $\begin{array}{l}\text { Organizational } \\
\text { Commitment }\end{array}$ & $\begin{array}{l}\text { 1- I am willing to put in a great deal of effort } \\
\text { beyond that normally is expected in order to } \\
\text { help this organization to be successful. } \\
\text { 2- I talk up this organization to my friends as a } \\
\text { great organization to work for. } \\
\text { 3- I feel great loyalty to this organization. } \\
\text { 4- I found that my values and the } \\
\text { organization's values are very similar. } \\
\text { 5- I am proud to tell others that I am part of } \\
\text { this organization. } \\
\text { 6- This organization really inspires the very } \\
\text { best in me in the way of job performance. } \\
\text { 7- I am extremely glad that I choose this } \\
\text { organization to work for over others I was } \\
\text { considering at the time joined. } \\
\text { 8- I really care about the fate of this organization. }\end{array}$ & $\begin{array}{l}\text { Porter et al. } \\
\text { (1974) }\end{array}$ \\
\hline 3 & Job Satisfaction & $\begin{array}{l}\text { 1)My basic salary is sufficiently paid according to } \\
\text { my daily working hours and workload } \\
\text { 2) I am satisfied with my chances for salary } \\
\text { increases. } \\
\text { 3) The work I do is appreciated. } \\
\text { 4) I believe those that do well on the job have fair } \\
\text { chances of being promoted. } \\
\text { 5) It is possible to get promoted fast in my job. }\end{array}$ & $\begin{array}{l}\text { Cohen et al. } \\
\text { (1983) }\end{array}$ \\
\hline 4 & Job stress & $\begin{array}{l}\text { 1) How often have you felt nervous and "stressed"? } \\
\text { 2) How often have you found that you could not } \\
\text { cope with all the things that you had to do? } \\
\text { 3) How often have you been angered because of } \\
\text { things that happened that been outside your }\end{array}$ & $\begin{array}{l}\text { Cohen et al. } \\
\text { (1983) }\end{array}$ \\
\hline
\end{tabular}




\begin{tabular}{|c|c|c|c|}
\hline & & $\begin{array}{l}\text { control? } \\
\text { 4) How often have you felt that difficulties were } \\
\text { increasing that you could not overcome them? }\end{array}$ & \\
\hline 5 & $\begin{array}{l}\text { Leadership } \\
\text { support }\end{array}$ & $\begin{array}{l}\text { 1) My supervisor asks employees for their } \\
\text { suggestions on what assignments should be made } \\
\text { 2) My supervisor gives advance notice of changes } \\
\text { 3) My supervisor treats all the employees s/he } \\
\text { supervises as his/her equal } \\
\text { 4). My supervisor is friendly and approachable } \\
\text { 5) My supervisor asks employees for their } \\
\text { suggestions concerning how to carry out } \\
\text { assignments }\end{array}$ & $\begin{array}{l}\text { House and } \\
\text { Dessler } \\
\text { (1974) }\end{array}$ \\
\hline
\end{tabular}

\subsection{Procedure}

The questionnaire was distributed among 200 respondents in Bahawalpur. These respondents are selected based on the criteria above mentioned. Before giving the questionnaire, the purpose of study and questions were explained to the respondents so they can easily fill the questionnaire will relevant responses. A total of 150 questionnaires were selected and rest of the questionnaire was not included in the further analysis due to complete or invalid response. After collecting the completed questionnaires, these questionnaires were coded and entered into spss sheet for further analysis.

\subsection{Reliability Analysis}

Table 2: Reliability of measuring instrument

\begin{tabular}{|l|l|l|}
\hline Scales & Items & Cronbach alpha \\
\hline Employee turnover intention & 3 & 0.857 \\
Organizational commitment & 8 & 0.864 \\
Job satisfaction & 5 & 0.755 \\
Leadership support & 5 & 0.836 \\
Job stress & 4 & 0.814 \\
& & \\
\hline
\end{tabular}




\section{Macrothink \\ International Journal of Human Resource Studies \\ ISSN 2162-3058 \\ 2014, Vol. 4, No. 2}

\section{Results and Analysis}

\subsection{Profile of the Respondent}

Personal and demographic information such as gender, age, income, education and company are presented in the following table.

Table3: profile of the respondent

\begin{tabular}{|c|c|c|c|}
\hline Variables & Category & Frequency & Percentage \\
\hline Gender & $\begin{array}{l}\text { Male } \\
\text { Female }\end{array}$ & $\begin{array}{l}87 \\
63\end{array}$ & $\begin{array}{l}58 \\
42\end{array}$ \\
\hline Age & $\begin{array}{l}\text { 15-20 years } \\
20-25 \text { years } \\
25-30 \text { years } \\
30-35 \text { years } \\
35-40 \text { years } \\
\text { Above } 40 \text { years }\end{array}$ & $\begin{array}{l}3 \\
48 \\
47 \\
18 \\
16 \\
18\end{array}$ & $\begin{array}{l}2 \\
32 \\
31.3 \\
12 \\
10.7 \\
12\end{array}$ \\
\hline Income(Rs/month) & $\begin{array}{l}\text { Below } 15000 \\
15000-25000 \\
25000-35000 \\
35000-45000 \\
45000-55000 \\
\text { Above } 55000\end{array}$ & $\begin{array}{l}25 \\
59 \\
20 \\
23 \\
11 \\
12\end{array}$ & $\begin{array}{l}16.7 \\
39.3 \\
13.3 \\
15.3 \\
7.3 \\
8\end{array}$ \\
\hline Education & $\begin{array}{l}\text { Matriculation } \\
\text { Inter } \\
\text { Bachelor } \\
\text { Master } \\
\text { MS/M.phill } \\
\text { PHD }\end{array}$ & $\begin{array}{l}0 \\
3 \\
36 \\
92 \\
19 \\
0\end{array}$ & $\begin{array}{l}0 \\
2 \\
24 \\
61.3 \\
12.7 \\
0\end{array}$ \\
\hline
\end{tabular}




\begin{tabular}{l} 
Macrothink $\begin{array}{r}\text { International Journal of Human Resource Studies } \\
\text { ISSN 2162-3058 } \\
\text { 2014, Vol. 4, No. 2 }\end{array}$ \\
\begin{tabular}{|l|l|l|l|}
\hline \\
\hline
\end{tabular} \\
\hline Comptitute
\end{tabular}

\subsection{Hypothesis testing}

\subsubsection{Organizational commitment and turnover intention}

According to the results of the study, the variable has a significant negative relationship with turnover intention. Specifically, the organizational commitment has a negative relationship with $(\beta=-0.570)$ and $(p<0.001)$.that means the organizational commitment contribute $57 \%$ to employee turnover intention. Results of current study validate the H1.

\subsubsection{Job satisfaction and turnover intention}

The regression results of the study confirms the significant negative relation between job satisfaction and turnover intention with $(\beta=-0.147)$ and $(p<0.05)$. Job satisfaction contributes more than $14 \%$ to turnover intention. Current study validates the $\mathrm{H} 2$.

\subsubsection{Job satisfaction and organizational commitment}

The analysis shows that job satisfaction has significant positive relationship with organizational commitment with $(\beta=0.407)$ and $(p<0.001)$. Job satisfaction contributes more than $40 \%$ to organizational commitment. Results validate the $\mathrm{H} 3$.

\subsubsection{Job stress and job satisfaction}

Regression estimates results shows that the job stress has significant inverse relationship with job satisfaction with $(\beta=-0.133)$ and $(p<0.05)$.Job stress contribute more than $13 \%$ to job satisfaction. The current study validates $\mathrm{H} 4$.

\subsubsection{Job stress and turnover intention}

The regression analysis results shows that job stress has a positive relation with turnover intention with a $(\beta=0.116)$ and $(\mathrm{p}<0.05)$.the results accepted the H5.

\subsection{Leadership support and job satisfaction}

The leadership support has a positive influence on job satisfaction. The analysis shows that $(\beta=0.408)$ and $(p<0.001)$.Leadership support contribute more than $40 \%$ to the job satisfaction. The current analysis accepted the H6. 
Table 5: Regression Result

\begin{tabular}{|c|c|c|c|c|c|c|}
\hline Hypothesis & Model variables & Estimate & S.E & C.R & $\mathrm{P}$ & Results \\
\hline HI & $\begin{array}{l}\text { Org } \\
\text { TOI }\end{array}$ & -0.570 & 0.129 & -4.409 & 0.000 & Supported \\
\hline $\mathrm{H} 2$ & $\begin{array}{l}\text { Job } \longrightarrow \text { sat } \\
\text { TOI }\end{array}$ & -0.147 & 0.117 & -1.803 & 0.014 & Supported \\
\hline H3 & $\begin{array}{l}\text { Jobsat } \\
\text { Org cmt }\end{array}$ & 0.407 & 0.068 & 5.428 & 0.000 & Supported \\
\hline $\mathrm{H} 4$ & $\begin{array}{l}\text { Job } \longrightarrow \text { stress } \\
\text { Job sat }\end{array}$ & -0.133 & 0.057 & -2.432 & 0.035 & Supported \\
\hline H5 & $\begin{array}{l}\text { Jobstress } \longrightarrow \\
\text { TOI }\end{array}$ & 0.116 & 0.081 & 2.079 & 0.027 & Supported \\
\hline H6 & $\begin{array}{l}\text { Ldspt } \\
\text { Job sat }\end{array}$ & 0.408 & 0.073 & 5.364 & 0.000 & Supported \\
\hline
\end{tabular}

\section{Discussion}

The primary objective of the study has been to study the turnover intention in the private and public sector institutions. The objective is to establish the relationship between commitment to organization and turnover intention. The correlation analysis from this study proved past researchers that higher commitment links with lower intention to quit the organization employees are less likely to leave the organization when they are emotionally attach with their organization. The commitment of employees which is high, they are more preferred to stay and work with the organization rather than leave the organization. Thus, commitment to organizational has a negative relationship to affect turnover intention. It contributes about $50 \%$ in turnover intention. Large number of research is present who link job Satisfaction to turnover intentions (Williams et al., 2001). Job satisfaction and Organizational Commitment are popular topics in the study of occupational attitudes (Kontoghiorghes and Bryant,2004; Testa, 2001). The relationship of job Satisfaction to turnover intentions is further supported by a numerous studies these studies identify Job satisfaction as an antecedent of organizational commitment (Lin and Ma, 2004b; Tett and Meyer,1993). Outcome of many studies have provided confirmation that there is a Strong negative relationship between job satisfaction and turnover intentions (Mannheim et al., 1997; Abraham, 1999). The more the individual satisfied with the performance and work environment his/her intention to leave the organization is low as they are more committed to organization. The person feeling burden in 
work in accordance to various attitudes as salary or other compensation plans they prefer to leave the organization and are having low satisfaction. Job satisfaction influence leadership supports more for internals than externals. Leadership support can enhance worker self-confidence, particularly for that worker who lack work experience, consequently, leading to higher organizational commitment and job satisfaction, and lower turnover intentions. The studies shows that to maintain lower employee turnover an organization must have highly commitment employees which are satisfied by the working conditions, compensation, leadership and low work load. Lesser the turnover intention lesser would be the cost of recruiting, selecting, training and development. Findings prove the significant relations of all the variables of the hypothesis.

\section{Limitations and future research}

This current research paper has numerous limitations. First the respondent response may be bias and they misrepresent their attitude .secondly, in this current study data is only gathered from one city, so from different cities it can be gathered. Current study only focuses on urban area turnover rate. Thirdly the sample size not too much and number of females are far less than males. In future equal ratio can be taken. No PHD employee is included in this current research. Fourthly this current study is conducted during recession era; results may be different in case of boom period. Fifthly the numbers of variables included in current study is less so more variables can be taken for study.

\section{References}

Abraham, R. (1999), "The impact of emotional dissonance on organizational commitment and intention to turnover", The Journal of Psychology, Vol. 133 No. 4, pp. 441-55.

Blau, G.J. (1987), "Locus of control as a potential moderator of the turnover process", Journal of Occupational Psychology, Vol. 60 No. 1, pp. 21-9.

Brown, S.P. and Peterson, R.A. (1993), “Antecedents and consequences of salesperson job satisfaction: meta-analysis and assessment of causal effects", Journal of Marketing Research, Vol. 30 No. 1, pp. 63-77.

Barsky, A., Thoresen, C.J., Warren, C.R. and Kaplan, S.A. (2004), "Modeling negative affectively and job stress: a contingency-based approach”, Journal of Organizational Behavior, Vol. 25 No. 8, pp. 915-36

Byham, W.C., \& Wilson, J.M. (1991). Empowered teams San Francisco: Jossey-Bass. Williams, S.V. (2003). An empirical investigation of turnover intentions of internal auditors. Dissertation Abstract International Section A: Humanities and Social Sciences, 64(5- A), 174

Cohen, J. and Cohen, P. (1988), Applied Multiple Regression/Correlation Analysis of the BehaviorScience, 3rd ed., Lawrence Erbaum Associates, Hillsdale, NJ.

Cummins, R. (1989), "Locus of control and social support: clarifiers of the relationship between job stress and job satisfaction”, Journal of Applied Social Psychology, Vol. 19 No. 9, pp. $772-88$. 


\section{MInstitute Macrothink $_{\text {Int }}$}

International Journal of Human Resource Studies

ISSN 2162-3058

2014, Vol. 4, No. 2

Emst, M.E., Franco, M., Messmer, P.R. and Gonzalez, J.L. (2004), “Nurses' job satisfaction, stress,and recognition in a pediatric setting”, Pediatric Nursing, Vol. 30 No. 3, pp. 219-27.

Firth, L., Mellor, D.J., Moore, K.A., \& Loquet, C. (2004). How can managers reduce employee intention to quit? Journal of Managerial Psychology, 19(2), 170-187. Ford, R.C., \& Fottler, M.D. (1995).

Harrison, R. (1972). Understanding your organization's character, Harvard Business Review, 119-128.

House, R.J. and Dessler, G. (1974), "The path-goal theory of leadership: some post hoc and a prioritests", in Hunt, J. and Arson, L. (Eds), Contingency Approaches to Leadership, Southern Illinois University Press, Carbondale, IL.

Jeffrey Pfeffer (2007) Human Resources from an Organizational Behavior Perspective: Some Paradoxes Explained The Journal of Economic Perspectives Vol. 21, No. 4. pp. 115134

Kontoghiorghes, C. and Bryant, N. (2004), "Exploring employee commitment in a service organization in the health care insurance industry", Organization Development Journal, Vol. 22 No. 3, pp. 59-73

Lee, R.T. and Ashforth, B.E. (1993), "A further examination of managerial burnout: toward an integrated model”, Journal of Organizational Behavior, Vol. 14 No. 1, pp. 3-20.

Liu,B.C.,Liu,J.X.,\&Hu,J.(2010). Person-organization fit, Job satisfaction and turnover intention: A empirical study in the Chinese Public Sector. Social behavior and Personality, $38(5), 615-626$.

McCarthy, G., Tyrrell, M.P., \& Lehane, E. (2007). Intention to 'leave' or 'stay' in nursing. Journal of Nursing Management, 15, 248-255.

Mathieu, J.E. and Zajac, D.M. (1990), "A review and meta-analysis of the antecedents, correlates, and consequences of organizational commitment", Psychological Bulletin, Vol. 108 No. 2, pp. 171-94

Mahmood A. Bodla \& Abdul Hameed.(2008). Factors Affecting Employee Turnover Intentions: Empirical Evidence from Textile Sector of Pakistan.The International Journal of Knowledge, Culture and Change Management. 9(8) , pp.53-64

Nunnally, J.C., \& Bernstein, I.H. (1994). Psychometric theory (3rd edn.). New York: McGraw-Hill.

Rizwan, M., Shahid, M., Shafiq, H., Tabassum, S., Bari, R. \& Umer, J. (2013) Impact of Psychological Factors on Employee Turnover Intentions, International Journal of Research in Commerce, Economics and Management, 3(3), 63-69

Netemeyer, R.G., Boles, J.S., McKee, D.O. and McMurrian, R. (1997), “An investigation into the antecedents of organizational citizenship behaviors in a personal selling context", Journal of Marketing, Vol. 61 No. 3, pp. 85-98. 
Peralta, M., \& Stark, A. (2006). South Africa: A crossover from inward thinking to a global outlook. Chemical Week, 168(35), 41-52.

Porter, L.W., Steers, R.M., Mowday, T.T. and Boulian, P.V. (1974), "Organizational commitment,job satisfaction, and turnover among psychiatric technicians”, Journal of Applied Psychology, Vol. 59 No. 5, pp. 603-9.

Randolph, W.A. (1995). The leadership challenge of changing to a culture of empowerment. Executive Development, 8(1), 5-8.

R.M. and Porter, L.W. (1979), “The measurement of organizational commitment”, Journal of Vocational Behavior, Vol. 14 No. 2, pp. 224-7.

Scholarios, D. and Marks, A. (2004), "Work-life balance and the software worker", Human Resource Management Journal, Vol. 14 No. 2, pp. 54-74. Spector, P.E. (1982),

Testa, M.R. (2001), "Organizational commitment, job satisfaction, and effort in the service environment", The Journal of Psychology, Vol. 135 No. 2, pp. 226-36.

Tett, R.P. and Meyer, J.P. (1993), "Job satisfaction, organizational commitment, turnover intention, and turnover: path analyses based on meta-analytic findings", Personnel Psychology, Vol. 46 No. 2, pp. 259-91.

Vandenberghe,C.,\&Bemtein,K.(2009). A closer look at the relationship between affective commitment to supervisor $\mathrm{s}$ and organizations and turnover. Journal of Occupational and Organizational Psychology, 82,331-348.

Van Dick, R., Christ, O., Stellmacher, J., Wagner, U., Ahlswede, O., Grubba, C. et al.,(2004). Should I stay or should I go? Explaining turnover intentions with organizational identification and job satisfaction. British Journal of Management, 15, 351-360.

Rizwan, M., Sajid, H. H. U., Kamran, M., Mohsin, M., Ali, N. and Sajid, H. M. (2013) Determinants of Turnover Intentions in Government and Private Employees: An Empirical Study from Pakistan, IOSR Journal of Business and Management, Vol. 1 (special issue), 44-51

Van Dierendonck, D., Haynes, C., Borrill, C., \& Stride, C. (2004). Leadership behavior and subordinate well-being. Journal of Occupational Health Psychology, 9, 165-175.

Williams, E.S., Konrad, T.R., Scheckler, W.E., Pathman, D.E., Linzer, M., McMurray, J.E.,

Gerrity,M. and Schwartz, M. (2001), “Understanding physicians' intentions to withdraw from practice: the role of job satisfaction, job stress, mental and physical health", Health Care Management Review, Vol. 26 No. 1, pp. 7-19.

Williams et al., 2001: "Measuring physician job satisfaction in a changing workplace and a challenging environment", Medical Care,Vol. 37 No. 11, pp. 1174-82.

Z.M.B., Mellor, D., Moore, K.A., \& Firth, L. (2006). Predicting intention to quit in the call centre industry: Does the retail model fit? Journal of Managerial Psychology, 21, 231-243 